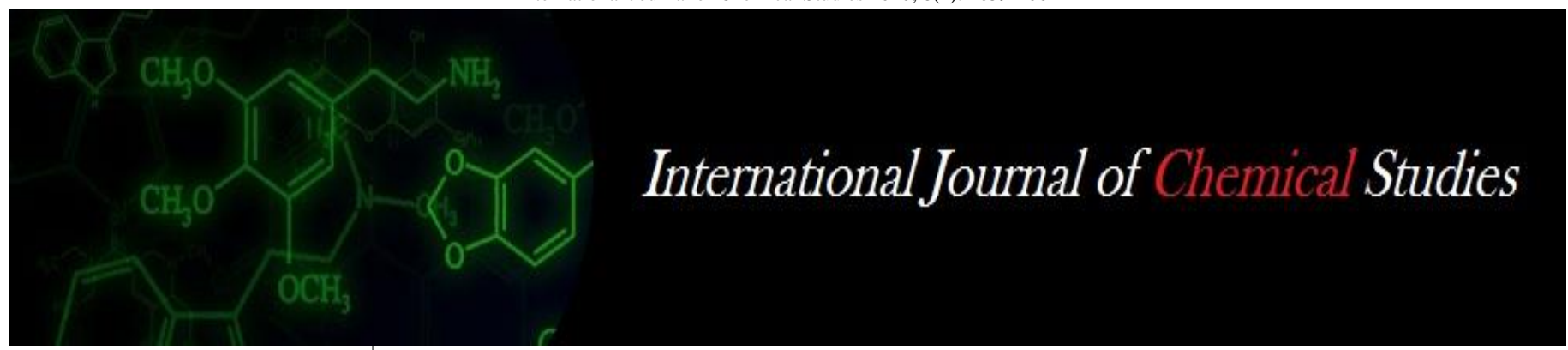

P-ISSN: 2349-8528

E-ISSN: 2321-4902

www.chemijournal.com

IJCS 2020; 8(4): 2059-2062

(C) 2020 IJCS

Received: 22-05-2020

Accepted: 24-06-2020

Abha Parashar

Subject Matter Specialist,

Krishi Vigyan Kendra, Sirohi,

Rajasthan, India

Sudesh Sharma

Director, Rajasthan Agricultural

Research Institute, Sri Karan

Narendra Agriculture

University, Jobner, Jaipur,

Rajasthan, India

Prerna Dogra

Assistant Professor,

Sri Karan Narendra Agriculture

University, Jobner, Jaipur,

Rajasthan, India

Kamini Parashar

Subject Matter Specialist,

Krishi Vigyan Kendra, Sirohi,

Rajasthan, India

BS Tyagi

(1). Assistant Professor,

Sri Karan Narendra Agriculture

University, Jobner, Jaipur,

Rajasthan, India

(2). Assistant Professor,

Jagganath Univrersity, Chaksu,

Jaipur, Rajasthan
Corresponding Author:

Abha Parashar

Subject Matter Specialist,

Krishi Vigyan Kendra, Sirohi,

Rajasthan, India

\section{Response of malt barley (Hordeum vulgare L.) varieties to different levels of nitrogen and sulphur application under agro-climatic zone IIIa (Semi-arid eastern plain zone) of Rajasthan}

\author{
Abha Parashar, Sudesh Sharma, Prerna Dogra, Kamini Parashar and BS \\ Tyagi
}

DOI: https://doi.org/10.22271/chemi.2020.v8.i4v.9932

\begin{abstract}
Field studies were carried out to investigate the effect of different nitrogen and sulphur applications on growth parameters, yield and quality parameters of two row malt barley varieties conducted at research farm, Rajasthan Agricultural Research Institute, Durgapura for two consecutive rabi seasons 2015-16 and 2016-17 on loamy sand soil. The twenty seven treatment combinations consisting of 3 varieties (RD 2849, DWRUB 52 and RD 2668), 3 nitrogen levels (60 kg, $90 \mathrm{~kg}$ and $120 \mathrm{~kg}$ ) and 3 sulphur levels (0 kg, $10 \mathrm{~kg}$ and $20 \mathrm{~kg}$ ) were tested in factorial randomized block design with three replications. The results indicated that variety RD 2849 proved significantly superior to DWRUB 52 and RD 2668 with respect to yield (grain and straw yield $\left(\mathrm{q} \mathrm{ha}^{-1}\right)$ ) and quality parameters (Starch content $(\%)$. In case of nitrogen and sulphur applications grain and straw yield $\left(\mathrm{q} \mathrm{ha}{ }^{-1}\right)$, Crude protein content $(\%)$ and Starch content (\%) of barley were improved. The highest grain and straw yield $\left(\mathrm{q} \mathrm{ha}^{-1}\right)$, Crude protein content $(\%)$ and Starch content (\%) of barley obtained with $120 \mathrm{~kg} \mathrm{~N} \mathrm{ha}^{-1}$ and $20 \mathrm{~kg} \mathrm{~S} \mathrm{ha}^{-1}$ and it was found statically at par with $90 \mathrm{~kg} \mathrm{~N} \mathrm{ha}^{-1}$ and $10 \mathrm{~kg} \mathrm{~S} \mathrm{ha}^{-1}$ application.
\end{abstract}

Keywords: Hordeum vulgare L., nitrogen, sulphur, agro-climatic

\section{Introduction}

Barley (Hordeum vulgare L.) is an ancient cereal crop, which is used as food grain to a feed and malting grain (Baik and Ullrich 2008; Pourkheirandish and Komatsuda 2007) ${ }^{[4,9]}$. It is considered fourth largest grown cereal crop in the world with a share of $7 \%$ of the global cereal production (Pal et al., 2012) ${ }^{[7]}$. Barley is also used as animal fodder, as a source of beverages and as a constituent of various health foods. The barley grains products such as "Sattu" (in summers because of its cooling effects on human body) and Missi Roti have been traditionally used in India (Verma et al. 2011) ${ }^{[12]}$.

Barley ranks next to wheat both in area and production among rabi cereals in India. It is because of its less water requirement and fairly tolerance to salinity, alkalinity, frost and drought situations. Barley is generally grown on marginal and sub-marginal land farmers because of its low inputs. In Rajasthan, it is mostly grown on light texture soils that having low nitrogen and organic matter content with poor moisture retentive capacity.

Adequate mineral fertilization is considered to be one of the most important requirements for better yield. The major production constraints in barley growing areas are their low fertility status in general and deficiency of nitrogen in particular. Nitrogen is one of the essential nutrient that is universally deficient in most of the Indian soils particularly in the loamy sand soils of semi-arid regions of Rajasthan (Chhonkar and Rattan 2000) ${ }^{[3]}$. It is the most important growth limiting factor in non-legumes (Zebarth et al. 2009) ${ }^{[13]}$.

Sulphur is also an essential nutrient for plants that helps in formation of important enzymes and assists in the formation of plant proteins. Enhanced removal of sulphur due to exploitation agriculture seems to be principal cause for occurrence of progressive incidence of sulphur deficiency. The interaction of nitrogen and sulphur is generally positive and occasionally additive. It has been established that for every 15 parts of nitrogen in proteins, there is one part of sulphur which implies that $\mathrm{N}-\mathrm{S}$ ratio is fixed within narrow 15:1 range. 
Therefore, deficiency of sulphur will decrease the amount of protein synthesized even if there is plenty of $\mathrm{N}$ available to the plant. The aim of this study was to investigate the effect of different levels of sulphur and nitrogen amounts on yield and some quality components of barley grown on loamy sand soil.

\section{Materials and Methods}

The experiment was conducted at Rajasthan Agricultural Research Institute, Durgapura, Jaipur (Rajasthan) during Rabi seasons of 2015-16 and 2016-17, geographic location of the place is $75^{\circ} 47^{\prime}$ East longitude, $26^{0} 51^{\prime}$ North latitude and altitude of $390 \mathrm{~m}$ above mean sea level. The climate of this place is semi-arid characterized by extremity of temperature both in summer $\left(45.5^{\circ} \mathrm{C}\right)$ and winter $\left(4{ }^{\circ} \mathrm{C}\right)$ and aridity of the atmosphere. The rainfall of the region is between 500-700 $\mathrm{mm}$ per annum which is mostly received during July to September. The experimental soil (0.0-0.15 m depth) analysed using the standard methods had shown $\mathrm{pH} 8.1$ and 7.8, EC

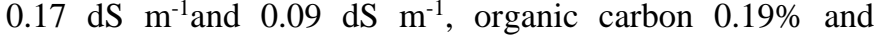
$0.24 \%$, available $\mathrm{N} 134.2$ and $139.2 \mathrm{~kg} \mathrm{ha}^{-1}$, available $\mathrm{P}_{2} \mathrm{O}_{5}$ 36.5 and $42.5 \mathrm{~kg} \mathrm{ha}^{-1}$, available $\mathrm{K}_{2} \mathrm{O} 180.7$ and $186.8 \mathrm{~kg} \mathrm{ha}^{-1}$, available Sulphur 7.10 and 8.75 ppm during the year 2015-16 and 2016-17, respectively. The treatments were consisted of three varieties RD-2668 (V1), DWRUB-52 (V2), RD-2849 (V3), three nitrogen levels 60 (N1), 90 (N2) and $120 \mathrm{~kg} \mathrm{ha}^{-1}$ (N3) and three sulphur levels 0 Control (S1), 10 (S2) and 20 $\mathrm{kg} \mathrm{ha}{ }^{-1}$ (S3).The experiments were laid out in Factorial Randomized Block Design (RBD) with three replications. The treatments were randomly allotted to different plots using random number table of Fisher and Yates (1963) ${ }^{[4]}$. As per treatment, fertilizers were applied through urea, DAP and gypsum. Full dose of phosphorus and sulphur with half dose of nitrogen were applied as basal, while remaining nitrogen was top dressed according to treatments. The barley varieties viz. RD 2668, DWRUB-52 and RD 2849 were sown on $15^{\text {th }}$ and $19^{\text {th }}$ November during 2015 and 2016 as per treatments. A uniform seed rate of $100 \mathrm{~kg} \mathrm{ha}^{-1}$ was used at inter row spacing of $20 \mathrm{~cm}$. In order to obtain uniform plant stand, seeds were weighed for each plot separately in small packets before sowing. Sowing was done manually in furrows, followed by irrigation. Five plants were randomly selected from each plot and tagged for required measurements. After harvesting, these samples were dried in sunlight for 2-3 days and finally dried in oven at $70{ }^{\circ} \mathrm{C}$ till constant weight was obtained. Thereafter, the samples were weighed for estimating total dry matter accumulation $(\mathrm{g})$ at the above mentioned growth stages. After threshing and winnowing, grain yield per plot was weighed and expressed in terms of $\mathrm{q} \mathrm{ha}{ }^{-1}$. Straw yield was obtained by subtracting the grain yield per plot from the respectively biological yield plot $^{-1}$ and expressed in terms of $\mathrm{q} \mathrm{ha}^{-1}$.

For recording crude protein and starch content in percentage samples of grain were taken replication wise and predicted using FOSS NIR system and expressed on dry weight basis. To record the husk content in percent, sodium hypochlorite method (dry basis) as per EBC method was used to determine the husk content in barley grain. To test the significance of variation in experimental data of various treatment effects, the data were statistically analyzed as described by Panse and Sukhatme (1985) ${ }^{[8]}$.

\section{Results and Discussion \\ Barley Yield}

Barley varieties differ significantly in the grain and straw yield during both the year of experiment and on pooled data (Table 1). On the basis of pooled data, RD 2849 increased the grain yield by 9.21 and $12.91 \%$ as compared to varieties DWRUB 52 and RD 2668 respectively. Similarly, variety RD 2849 also recorded the highest straw yield (58.67 q ha-1) and showed significant increase of 7.29 and $8.18 \%$, respectively, over varieties DWRUB 52 and RD 2668 based on pooled analysis. Chakravarty and Kushwah (2007) ${ }^{[2]}$ also reported the highest grain yield of variety RD 2552 among three varieties i.e. RD 2552, K 560 and DL 88. Nitrogen application of $120 \mathrm{~kg} \mathrm{~N} \mathrm{ha}^{-1}$ also brought significantly higher grain yield compare to control and but was found at par with $90 \mathrm{~kg} \mathrm{~N} \mathrm{ha}^{-}$ ${ }^{1}$ (Table 1). Application of $120 \mathrm{~kg}$ and $90 \mathrm{~kg} \mathrm{~N}$ ha-1 increased the grain yield of barley by 23.07 and $18.15 \%$ as compared to control, respectively, in pooled data. Similarly, application of $120 \mathrm{~kg} \mathrm{~N}$ ha-1 recorded the highest straw yield and proved superior to control and was found at par with $90 \mathrm{~kg} \mathrm{~N}$ ha-1 during both the years of experiment as well as in pooled analysis. Straw yield was recorded higher with increasing rates of $\mathrm{N}$ application might be due to improved biomass per plant at successive growth stages and increase in various morphological parameters like plant height, number of tillers etc. it has been also reported by Katiyar and Uttam (2007) ${ }^{[6]}$ in barley and Jat et al. (2014) ${ }^{[5]}$ in wheat. Sharma and Verma (2010) ${ }^{[11]}$ also documented the significant positive influence of nitrogen on yield of barley. Sulphur significantly increased grain and straw yield during both the years of experiment as well as on pooled analysis. Among sulphur levels, application of $20 \mathrm{~kg}$ and $10 \mathrm{~kg} \mathrm{~S} \mathrm{ha}^{-1}$ increased the grain yield by 11.00 and $8.53 \%$ as compared to control, while the treatment $20 \mathrm{~kg}$ $\mathrm{S}$ ha-1 was found at par with treatment $10 \mathrm{~kg} \mathrm{~S} \mathrm{ha}^{-1}$. As grain yield is primarily a function of cumulative effect of growth parameters and yield attributing characters, the higher values of these attributes because of sulphur and nitrogen application can be assigned as the most probable reason for significantly higher grain yield. Application of $20 \mathrm{~kg} \mathrm{~S}^{-1}$ recorded the highest straw yield and proved superior to control and was found at par with $10 \mathrm{~kg} \mathrm{~S}$ ha $^{-1}$ during both the years of experiment as well as in pooled analysis. On the basis of pooled data, application of $20 \mathrm{~kg}$ and $10 \mathrm{~kg} \mathrm{~S}^{-1}$ increased the straw yield by 8.82 and $6.64 \%$ as compare to control.

\section{Quality parameters \\ Crude protein (\%)}

Varieties did not cause any significant variation in crude protein content during both the years of experimentation and in pooled analysis (Table 2). Nitrogen bought significant variation in crude protein during both the years of experimentation as well as in pooled analysis. Application of $120 \mathrm{~kg} \mathrm{~N} \mathrm{ha}^{-1}$ recorded the highest crude protein and proved significantly superior to control and was found at par with 90 $\mathrm{kg} \mathrm{N} \mathrm{ha}^{-1}$ during both the years of experimentation as well as in pooled analysis. Application of $120 \mathrm{~kg}$ and $90 \mathrm{~kg} \mathrm{~N} \mathrm{ha}{ }^{-1}$ increase the crude protein of barley by 12.80 and 11.08 per cent as compared to control, respectively, in pooled data. Similarly, application of $20 \mathrm{~kg} \mathrm{~S}^{-1}$ recorded the highest crude protein and proved significantly superior to control and was found at par with $10 \mathrm{~kg} \mathrm{~S} \mathrm{ha}^{-1}$ during both the years of experimentation as well as in pooled analysis. Application of

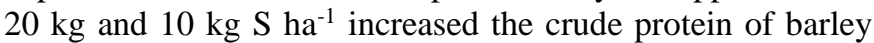
by 7.50 and 6.25 per cent as compared to control, respectively, in pooled analysis. Fathi et al. (1997) also reported an increase in the grain protein content upto highest rate of added $\mathrm{N}$ ( 0 to $105 \mathrm{~kg} \mathrm{~N} \mathrm{ha}^{-1}$ ). 


\section{Starch content $(\%)$}

Barley varieties responded significantly in the starch content during both the year of experimentation and on pooled basis. Variety RD 2849 proved significantly superior as compared to other varieties during both the years of experimentation. On the basis of pooled data, RD 2849 increased the starch content by 2.85 and 5.14 per cent, respectively as compared to variety DWRUB 52 and RD 2668. Nitrogen application significantly increased the starch content during both the years and in pooled analysis over control (Table 2). Among of nitrogen levels, application of $120 \mathrm{~kg} \mathrm{~N} \mathrm{ha}^{-1}$ recorded the highest starch content and proved significantly superior to control and was found at par with $90 \mathrm{~kg} \mathrm{~N} \mathrm{ha}^{-1}$ during both the years of experimentation as well as in pooled analysis. Application of $120 \mathrm{~kg}$ and $90 \mathrm{~kg} \mathrm{~N} \mathrm{ha}^{-1}$ increased the starch content of barley by 6.18 and 5.71 per cent as compared to control, respectively, in pooled data. Sulphur levels significantly increased starch content during both the years and in pooled analysis. Among of sulphur levels, application of $20 \mathrm{~kg} \mathrm{~S} \mathrm{ha}^{-1}$ recorded the highest starch content and proved significantly superior to control and was found at par with $10 \mathrm{~kg} \mathrm{~S} \mathrm{ha}^{-1}$ during both the years of experimentation as well as in pooled analysis. Application of $20 \mathrm{~kg}$ and $10 \mathrm{~kg} \mathrm{~S}^{-1}$ increased the starch content of barley by 9.47 and 8.10 per cent as compared to control, respectively, in pooled analysis (Table 2). Varieties, nitrogen levels and sulphur levels did not cause any significant variation in husk content during both the years of experimentation and pooled data.

\section{Correlation and regression}

Simple correlation and regression were worked out between grain yield and dry matter at physiological maturity, effective tillers, length of spike, number of grains per spike, test weight, malt yield, malt friability, malt homogeneity, hot water extract and hectoliter weight. The correlation coefficients and corresponding regression equations have been given in table 3 .

Correlation coefficient study revealed that the yield was significantly and positively correlated with dry matter at physiological maturity, effective tillers, length of spike, number of grains per spike, test weight, malt yield, malt friability, malt homogeneity, hot water extract and hectoliter weight. The corresponding values for correlation coefficients were $0.98,0.89,0.93,0.90,0.98,0.92,0.96,0.94,0.85 \& 0.97$ during 2015-16 and $0.98,0.85,0.93,0.92,0.98,0.90,0.97$, $0.94,0.86 \& 0.96$ during $2015-16$ and in pooled and 0.98 , $0.87,0.93,0.91,0.98,0.91,0.97,0.94,0.85 \& 0.97$ This indicates that yield attributes and malt quality parameters are directly correlated with the grain yield.

The regression equations show that with the increase in one unit in dry matter at physiological maturity, effective tillers, length of spike, number of grains per spike, test weight, malt yield, malt friability, malt homogeneity, hot water extract and hectoliter weight, the corresponding grain yield increased by $0.192,0.417,3.57,1.65,1.47,1.00,1.10,1.15,3.09 \& 1.16$ during 2015-16 and 0.173, 0.308, 3.60, 1.56, 1.25, 0.886, 1.05, $1.04,2.82 \& 1.04$ during $2016-17$ and in pooled $0.182,0.359$, $3.61,1.60,1.36,0.94,1.08,1.10,2.95 \& 1.10$ respectively.

Table 1: Response of malt barley varieties to nitrogen and sulphur on grain, straw yield and harvest index

\begin{tabular}{|c|c|c|c|c|c|c|}
\hline \multirow{2}{*}{ Treatments } & \multicolumn{3}{|c|}{ Grain yield $\left(q\right.$ ha $\left.^{-1}\right)$} & \multicolumn{3}{|c|}{ Straw yield $\left(q\right.$ ha $\left.^{-1}\right)$} \\
\hline & 2015-16 & 2016-17 & Pooled & 2015-16 & 2016-17 & Pooled \\
\hline \multicolumn{7}{|l|}{ Varieties } \\
\hline RD 2668 & 39.48 & 40.73 & 40.11 & 53.61 & 54.85 & 54.23 \\
\hline DWRUB 52 & 40.87 & 42.07 & 41.47 & 54.36 & 55.00 & 54.68 \\
\hline RD 2849 & 44.80 & 45.77 & 45.29 & 57.66 & 59.68 & 58.67 \\
\hline SEm \pm & 0.90 & 0.96 & 0.66 & 1.01 & 1.09 & 0.74 \\
\hline $\mathrm{CD}(\mathrm{P}=0.05)$ & 2.56 & 2.73 & 1.85 & 2.87 & 3.10 & 2.09 \\
\hline \multicolumn{7}{|c|}{ Nitrogen levels (kg/ha) } \\
\hline 60 & 36.43 & 37.92 & 37.18 & 50.03 & 50.53 & 50.28 \\
\hline 90 & 43.40 & 44.45 & 43.93 & 56.76 & 58.48 & 57.62 \\
\hline 120 & 45.32 & 46.20 & 45.76 & 58.84 & 60.52 & 59.68 \\
\hline SEm \pm & 0.90 & 0.96 & 0.66 & 1.01 & 1.09 & 0.74 \\
\hline $\mathrm{CD}(\mathrm{P}=0.05)$ & 2.56 & 2.73 & 1.85 & 2.87 & 3.10 & 2.09 \\
\hline \multicolumn{7}{|c|}{ Sulphur levels (kg/ha) } \\
\hline 0 & 38.90 & 40.50 & 39.70 & 52.25 & 53.99 & 53.12 \\
\hline 10 & 42.63 & 43.55 & 43.09 & 56.11 & 57.19 & 56.65 \\
\hline 20 & 43.62 & 44.52 & 44.07 & 57.27 & 58.35 & 57.81 \\
\hline SEm \pm & 0.90 & 0.96 & 0.66 & 1.01 & 1.09 & 0.74 \\
\hline $\mathrm{CD}(\mathrm{P}=0.05)$ & 2.56 & 2.73 & 1.85 & 2.87 & 3.10 & 2.09 \\
\hline
\end{tabular}

NS = Non significant

Table 2: Response of malt barley varieties to nitrogen and sulphur on crude protein, starch content and husk content

\begin{tabular}{|c|c|c|c|c|c|c|c|c|c|}
\hline \multirow{2}{*}{ Treatments } & \multicolumn{3}{|c|}{ Crude protein content (\%) } & \multicolumn{3}{c|}{ Starch content (\%) } & \multicolumn{3}{c|}{ Husk (\%) } \\
\cline { 2 - 11 } & $\mathbf{2 0 1 5 - 1 6}$ & $\mathbf{2 0 1 6 - 1 7}$ & Pooled & $\mathbf{2 0 1 5 - 1 6}$ & $\mathbf{2 0 1 6 - 1 7}$ & Pooled & $\mathbf{2 0 1 5 - 1 6}$ & $\mathbf{2 0 1 6 - 1 7}$ & Pooled \\
\hline Varieties & & & & & & & & & \\
\hline RD 2668 & 9.85 & 9.95 & 9.90 & 60.29 & 60.12 & 60.20 & 8.88 & 8.91 & 8.89 \\
\hline DWRUB 52 & 9.98 & 10.15 & 10.07 & 61.43 & 61.66 & 61.54 & 8.95 & 8.98 & 8.97 \\
\hline RD 2849 & 10.05 & 10.22 & 10.13 & 63.14 & 63.45 & 63.30 & 9.07 & 9.09 & 9.08 \\
\hline SEm \pm & 0.08 & 0.09 & 0.06 & 0.48 & 0.52 & 0.36 & 0.07 & 0.08 & 0.05 \\
\hline CD (P=0.05) & NS & NS & NS & 1.37 & 1.49 & 1.00 & NS & NS & NS \\
\hline Nitrogen levels (kg/ha) & & & & & & & & & \\
\hline 60 & 9.27 & 9.32 & 9.29 & 59.36 & 59.30 & 59.33 & 8.88 & 8.92 & 8.90 \\
\hline 90 & 10.21 & 10.44 & 10.32 & 62.60 & 62.84 & 62.72 & 8.99 & 9.00 & 9.00 \\
\hline 120 & 10.40 & 10.56 & 10.48 & 62.91 & 63.10 & 63.00 & 9.04 & 9.05 & 9.05 \\
\hline
\end{tabular}




\begin{tabular}{|c|c|c|c|c|c|c|c|c|c|}
\hline $\mathrm{SEm} \pm$ & 0.08 & 0.09 & 0.06 & 0.48 & 0.52 & 0.36 & 0.07 & 0.08 & 0.05 \\
\hline $\mathrm{CD}(\mathrm{P}=0.05)$ & 0.23 & 0.26 & 0.17 & 1.37 & 1.49 & 1.00 & NS & NS & NS \\
\hline Sulphur levels (kg/ha) & & & & & & & & & \\
\hline 0 & 9.50 & 9.69 & 9.59 & 58.15 & 58.39 & 58.27 & 8.88 & 8.91 & 8.90 \\
\hline 10 & 10.13 & 10.25 & 10.19 & 62.92 & 63.05 & 62.99 & 8.99 & 9.01 & 9.00 \\
\hline 20 & 10.25 & 10.38 & 10.31 & 63.79 & 63.79 & 63.79 & 9.03 & 9.06 & 9.05 \\
\hline SEm \pm & 0.08 & 0.09 & 0.06 & 0.48 & 0.52 & 0.36 & 0.07 & 0.08 & 0.05 \\
\hline CD (P=0.05) & 0.23 & 0.26 & 0.17 & 1.37 & 1.49 & 1.00 & NS & NS & NS \\
\hline
\end{tabular}

Table 3: correlation coefficients (r) and regression equations for the relationship between grain yield (Y) (q ha $\left.{ }^{-1}\right)$ and growth, yield attributing characters and quality parameters of crop (X)

\begin{tabular}{|c|c|c|c|c|c|c|c|}
\hline \multirow[t]{2}{*}{\begin{tabular}{|c|} 
S. \\
No.
\end{tabular}} & \multirow[t]{2}{*}{ Treatments } & \multicolumn{2}{|r|}{ 2015-16 } & \multicolumn{2}{|r|}{ 2016-17 } & \multicolumn{2}{|r|}{ Pooled } \\
\hline & & $\begin{array}{l}\text { Correlation } \\
\text { coefficient } \\
(\mathbf{r})\end{array}$ & $\begin{array}{l}\text { Regression equation } \\
\qquad \begin{array}{l}\mathrm{Y}=\mathbf{a}+\mathrm{b}_{\mathbf{y}} \mathbf{x} \cdot \mathbf{X}\end{array}\end{array}$ & $\begin{array}{c}\text { Correlation } \\
\text { coefficient (r) }\end{array}$ & $\begin{array}{l}\text { Regression equation } \\
\qquad \begin{array}{l}Y=a+b_{y} \mathbf{x} \cdot X\end{array}\end{array}$ & $\begin{array}{c}\text { Correlation } \\
\text { coefficient }(\mathbf{r})\end{array}$ & $\begin{array}{l}\text { Regression equation } \\
\qquad \mathbf{Y}=\mathbf{a}+\mathbf{b}_{\mathbf{y}} \mathbf{x} . \mathbf{X}\end{array}$ \\
\hline 1. & Dry $n$ & $0.981 * *$ & $Y=-4.840+0.192 \mathrm{X}_{1}$ & $0.983 * *$ & $Y=0.136+0.173 X_{1}$ & $0.982 * *$ & $\mathrm{Y}=-2.368+0.182 \mathrm{X}_{1}$ \\
\hline 2. & Effective tillers/plant & $0.890 * *$ & $\mathrm{Y}=-92.429+0.417 \mathrm{X}_{1}$ & & $Y-61717+$ & & $\mathrm{Y}-76281$ \\
\hline 3. & $\begin{array}{l}\text { Number of } \\
\text { grains/spike }\end{array}$ & $0031 * *$ & $=-49.981+3.575 X_{3}$ & $0.938 * *$ & $Y=-56.314+3.605 X_{3}$ & $0.938 * *$ & $\mathrm{Y}=-53825+3616 \mathrm{X}_{2}$ \\
\hline 4 & Spike length $(\mathrm{cm})$ & $0.909 * *$ & $\mathrm{Y}=23.432+1.657 \mathrm{X}_{4}$ & $21 * *$ & $\mathrm{Y}=25.389+1.561 \mathrm{X}_{4}$ & $0.915^{* *}$ & $\mathrm{Y}=24.399+1.609 \mathrm{X}_{4}$ \\
\hline 5 & Test weight (g) & $0.982 * *$ & $\mathrm{Y}=-28.419+1.474 \mathrm{X}_{4}$ & $0.985 * *$ & $Y=-21.420+1.257 \mathrm{X}_{5}$ & $0.986 * *$ & $\mathrm{Y}=-25.164+1.367 \mathrm{X}_{5}$ \\
\hline 6 & Malt yield & $0.925 * *$ & $\mathrm{Y}=-43.956+1.005 \mathrm{X}_{6}$ & $0.903 * *$ & $Y=-33.149+0.886 X_{6}$ & $0.915 * *$ & $\mathrm{Y}=-38.654+0.946 \mathrm{X}_{6}$ \\
\hline 7. & ility & & $\mathrm{Y}=-9.856+1.102 \mathrm{X}_{7}$ & & $\mathrm{Y}=-6.331+1.057 \mathrm{X}_{7}$ & & $\mathrm{Y}=-8.156+1.081 \mathrm{X}_{7}$ \\
\hline 8. & Malt homogeneity & $0.949 * *$ & $Y=-46.900+1.159 \mathrm{X}_{8}$ & $0.940 * *$ & $Y=-37.404+1.046 \mathrm{X}_{8}$ & $0.945^{* *}$ & $Y=-42.168+1.103 \mathrm{X}_{8}$ \\
\hline 9 & Hot water extract & $0.853 * *$ & $\mathrm{Y}=-206.531+3.091 \mathrm{X}_{9}$ & $0.860 * *$ & $Y=-184.053+2.823 X_{9}$ & $0.857 * *$ & $\mathrm{Y}=-195.318+2.958 \mathrm{X}_{9}$ \\
\hline 10 & Hectoliter weight & $0.970 * *$ & $\mathrm{Y}=-27.813+1.162 \mathrm{X}_{10}$ & $0.968 * *$ & $\mathrm{Y}=-20.809+1.046 \mathrm{X}_{10}$ & $0.970 * *$ & $=-24.415+1.105$ \\
\hline
\end{tabular}

** Significant at 1 per cent level of significance

\section{References}

1. Baik BK, Ullrich SE. Barley for food: Characteristics, improvement, and renewed interest. Journal of Cereal Science. 2008; 48:233-42.

2. Chakrawarty VK, Kushwaha KP. Performance of barley (Hordeum vulgare) varieties under sowing dates and nitrogen levels in Bundelkhand. Progressive Research. 2007; 2:163-64.

3. Chhonkar PK, Rattan RK. Soil Fertility Management for Sustainable Agriculture. Indian Farming. 2000; 49(11):26-31.

4. Fisher RA, Yates F. Statistical tables. Oliver and Boyd, Edinburgh, London, 1963.

5. Jat SL, Nepalia V, Choudhary J, Singh D. Effect of nitrogen and weed management on productivity and quality of durum wheat (Triticum durum). Indian Journal of Agronomy. 2014; 59(2):281-285.

6. Katiyar AK, Uttam SK. Effect of fertility levels and weed control measures on growth, yield attributes and yield of barley (Hordeum vulgare L.) under rainfed condition. Bhartiya Krishi Anusandhan Patrika. 2007; 22:324-326.

7. Pal D, Kumar S, Verma RPS. Pusa Losar (BHS 380) the first dual- purpose barley variety for northern hills of India. Indian Journal of Agricultural Sciences. 2012; 82:164 - 165 .

8. Panse VG, Sukhatme PV. Statistical Methods for Agricultural Workers. Indian Council of Agricultural Research. New Delhi, 1985.

9. Pourkheirandish M, Komatsuda T. The importance of barley genetics and demonstration in a global perspectives. Annals of Botany. 2007; 100:999-1008.

10. Sestak Z, Catsky J, Jarvis PG. Plant photosynthetic production: Manual of methods. Dr. W.junk N.V. Publishers, Den Haag, 1971.

11. Sharma RK, Verma RPS. Effect of irrigation, nitrogen and varieties on the productivity and grain malting quality in barley. Cereals Research Communication. 2010; 38:419-28.

12. Verma RPS, Kharub AS, Kumar D, Sarkar B, Selvakumar R, Singh R et al. Fifty years of coordinated barley research in India. Directorate of Wheat Research, Karnal-132001. Research Bulletin No. 2011; 27:46.

13. Zebarth BJ, Arsenault WJ, Moorehead S, Tapani Kunelius H, Sharifi M. Effect of fertilizer nitrogen management and plough-sown date for Italian ryegrass on soil nitrogen supply to a subsequent potato crop. Agronomy Journal. 2009 101:1573-1580. 